\title{
LYČIŲ VAIZDAVIMO YPATYBĖS LIETUVOS LAIKRAŠČIUOSE 1990-2000 METAIS
}

\author{
Daiva Sirtautienè \\ Klaipédos universitetas
}

\begin{abstract}
Anotacija
Straipsnyje pristatomi1990-2000 metų laikotarpiu Lietuvos laikraščiuose publikuotų tekstų apie lytis semantinès analizès, remiantis statistiniais duomenimis, rezultatai. Iš viso išanalizuoti 749 straipsniai, kuriuose aprašomi vyrai (363 tekstai) ir moterys (386 tekstai). Tyrimu siekta nustatyti lyčiu vaizdavimo tekstuose ypatybes per pirmajji Lietuvos nepriklausomybès dešimtmetį. Išskirti reikšmių, siejamų su lytimis, segmentai, jų sąsajos tekstuose apie moteris ir vyrus, atlikta lyginamoji lyčių atspindejjimo skirtumų analizè.

PAGRINDINIAI ŽODŽIAI: laikraščiai, lytis, teksto semantika, Lietuva.
\end{abstract}

\begin{abstract}
The article presents the results of semantic analysis based on statistical data of 1990-2000 y. texts about genders published in Lithuanian newspapers. In all 749 articles, which portray men (363) and women (386), were analysed. The research aimed to establish the peculiarities of gender portrayal in texts during the first decade of Lithuania's independence. Segments ofmeanings, related to genders, and their interrelations in the texts about men and women were distinguished, comparative analysis of gender portrayal differences was conducted.

KEY WORDS: newspapers, gender, text semantics, Lithuania.
\end{abstract}

DOI: http://dx.doi.org/10.15181/tbb.v74i2.1367

\section{Ivadas}

Lyčių funkcionavimo erdvė žurnalistikoje yra daugialypė: pradèti būtų galima nuo lygių teisių žurnalistikos darbo rinkoje ir baigti - žurnalistine produkcija, atskleidžiančia požiūrị ị lytis, jų santykius. Šie ir kiti aspektai, įvairiai abstrahuojami, tampa mokslininkų analizės objektu (Tereškinas, 2004; Liukinevičienè, 2005; Astrauskaitè, 2005; Djerf-Pierre, 2007; Armstrong, Wood, Nelson, 2006; Mater, 2007; Kazinec, 2008; Stundžè, 2009; Žvinklienè, 2009; Willis, 2010; Li, Lei, 2010; Desmond, Danilewicz, 2010; Cotter, 2011).

Ø. Holter (2005) teigimu, „,...] lyčių lygybès klausimai vis dar nelaikomi labai svarbiais. Lyčių lygybè iš esmès vis dar traktuojama kaip moterų problema“ (2005, p. 167). İdomu, kad šią autoriaus išreikštą mintị iš dalies iliustruoja L. Stundžès (2016) paskelbtas lyčių studijų mokslo komunikacijos 1992-2012 metų periodinių leidinių straipsniuose tyrimas. Autoré, atlikusi tematikos analizę, atkreipia dėmesį, $\mathrm{kad},[\ldots]$ apie vyrų padètį nebuvo rašoma, todèl teminè rubrika ir vadinasi Moteru padetis“" (p. 118). 
Kai kurių autorių nuomone, „pagrindinis veiksnys, turintis įtakos moterų padèčiai, yra visuomenès sąmonès (psichologijos) apraiškos, neleidžiančios keisti tradicinio požiūrio ị moteris ir jų vaidmenį visuomenèje bei šeimoje. Tokia visuomenès psichologija būdinga tiek vyrams, tiek moterims ir yra patriarchalinio auklëjimo ir patriarchalinès lyčių istorijos rezultatas“ (Trinkūnienė, Trinkūnas, 1999, p. 36). „Vaidmenų pasiskirstymas pagal lytis turi ir teorinį, ir praktini poveikị ekonomikai. Ekonomikos dėsniuose matoma, kad tai, kas yra laikoma „,vyrišku reikalu“, yra aukštesnès ,piniginès“ vertės negu tos veiklos rūšys, kurios laikomos „moteriškomis“ (Aidis, 1999, p. 61).

„Žiniasklaida - puiki erdvė atskleisti ir puoselèti vertybes, kaip kultūros sudedamają dalį“" (Sirtautas, Sirtautienè, 2013, p. 84). Tad šia prasme atrodytų, jog tam tikras požiūris ị lyčių santykius visuomenejje tiesiog yra kultūros dalis, atskleidžiamas, galimai ir kuriamas žiniasklaidoje.

Mokslinėje literatūroje kalbama apie pačios žurnalistų bendruomenès stereotipus, žurnalistų asmeninę saviraišką, pvz., J. Willis (2010) išskiria žurnalistų bendruomenės pasidalijimą pagal 6 kriterijus: geografinę padèti, rasę, etniškumą, lyti, tikẻjimą, socioekonominị lygị ir amžių. Mokslininko manymu, šie kriterijai neretai lemia ir žurnalisto kuriamos produkcijos kryptį. Taigi, atsižvelgiant tik ị vieną išskirtaji - lyties - kriterijų, matyti, kad žiniasklaidos produkciją kuria lytys, vienaip ar kitaip jas ir atspindedamos, palaikydamos arba ne stereotipus apie moteris bei vyrus.

Kaip teigia L. Liukinevičienė (2005), tyrusi lyčių visavertès partnerystės ugdymą laikraščiuose ,regioninių dienraščiu pirmieji puslapiai, demonstruojantys šališkumą, neobjektyvumą lyčių atžvilgiu, pristatydami vyrą ir moterị tradiciniuose socialiniuose vaidmenyse arba apskritai kurios nors lyties nematydami, demonstruoja asimetrišką, labiau vyrams palankią informaciją, teigia geresnes vyrų socializacijos galimybes, o tai liudija nepakankamą žurnalistų kompetenciją diegti naują požiūrị ị lyčių santykius“" (p. 103).

Štai M. Stonkienè (2003), atlikusi Lietuvos žurnalų paaugliams tyrimą, nustatė stereotipiškų vyrų ir moterų vaidmenų vaizdavimo gausą, pvz., profesijų aspektu: „Akivaizdu, kad moterims priskiriamos mažesnio prestižo profesijos (pvz., moteris - cirko artistè, gidè, kosmetologè, modelis, oru pranešèja, pardavėja, padavejja, šokeja, valytoja ir kt., vyras - cirko direktorius, dirigentas, futbolo treneris, gydytojas, inspektorius, kompozitorius, operatorius, pilotas, teisèjas, verslininkas ir kt.). Tai atskleidžia redukuotą moters socialinị reikšmingumą, jos socialinị antrarūšiškumą“ (p. 91).

Labai panašius rezultatus tais pačiais metais gavo ir R. Matkevičienė (2003), atlikusi Lietuvos televizijų produkcijos tyrimą, kurio rezultatai rodo vyraujančią 
„vyriškos“ ar „moteriškos“ profesijos esatị: vyras - verslininkas, žurnalistas, dizaineris, TV laidos vedejjas, advokatas, aktorius, policininkas, vadovas, nusikaltèlis $^{1}$, valstybės tarnautojas, muzikas, pardavejjas. Moterims priskiriamos profesijos: mokytoja, modelis, sekretorè, namų šeimininkè (p. 77).

Kaip matyti iš aukščiau tyrimuose išryškejjusių profesijų sąrašo, vyrams labiau priskirtinas aukštesnio socialinio statuso vaidmuo, tačiau socialinio reikšmingumo aspektu, pvz., vaikus auginantiems tėvams, dar būtų svarstytina, kiek svarbi yra jų vaikų mokytoja, palyginus su mokyklos direktoriumi.

Ryškią lyčių stereotipizaciją galima matyti ir žiniasklaidoje pateikiamose reklamose. „Stebint reklamas, atrodytų, kad moterų pomėgiai yra maisto gaminimas, skalbimas ir sauskelnių vaikams keitimas, o vyrų - alaus gèrimas ir automobiliai““ (Stundžienè, 2002, p. 13). Galima būtų pritarti autorei, žvelgiant ị reklamuojamų prekių asortimento prieskyras lytims. Tačiau atlikti tyrimai rodo (Sirtautienè, Sirtautas, 2013), kad moterys ir vyrai, kaip TV reklamos vertintojai, išties yra skirtingi: moterys reklamose vertina žemiškuosius, su jų funkcijomis susijusius dalykus (vaikus, namus, maistą), vyrams TV reklamose labiau patinka profesinè veikla, technika, erotika (p. 40-41). Beje, pasak A. Kazinec (2008), dabar vis daugiau reklamos užsakovų pripažįsta moters vaidmenų visuomenèje įvairovę, vaizduodami dalykines moteris, nesiskiriančias su diplomu. Ivyko stereotipų kaita: „supermamos“ ịvaizdis užleido vietą ,,supermoters“ paveikslui (p. 34).

Šiame straipsnyje pristatomas pirmojo Lietuvos nepriklausomybès dvidešimtmečio kompleksinio lyčių raiškos laikraščių žurnalistikoje tyrimo tęsinys. Anksčiau atlikti (1991 ir 2010 metų skersiniai pjūviai) temų specializacijos bei jos kaitos pagal lytis, laikraščių redakcijų pokyčių lyties aspektu tyrimai atskleide Lietuvos laikraščių žurnalistų bendruomenès feminizacijos procesą: moterų autorių paskelbtų publikacijų, lyginant tirtuosius periodus, analizuotuose laikraščiuose padaugejjo trečdaliu, panašiai tiek pat padidejjo moteru skaičius redakcijose, taip natūraliai ịvyko ir temų specializacijos kaita, kai ịprastai vyrų kuruojamomis temomis, pvz., politikos, teisėsaugos, ekonomikos, daugiau ėmè rašyti moterys (plačiau žr. Sirtautienè, Samulionytė, 2015).

Turint omenyje nustatytaji laikraščių žurnalistikos Lietuvoje feminizacijos procesą, kilo mintis atlikti laikraščių tekstų apie lytis, kuriuos ir kuria žurnalistai ar žurnalistès, analizę, galimai fiksuojančią minimo proceso atskleidimą tekstuose.

Pradèta nuo pirmojo dešimtmečio: čia pateikiami 1990-2000 metų laikotarpiu skirtinguose auditorijos aprèptimi laikraščiuose publikuotų straipsnių apie lytis semantinès analizès, remiantis statistiniais duomenimis, rezultatai.

İdomu pastebėti, kad nusikaltimai ypač dažni tekstuose apie vyrus (žr. toliau šiame straipsnyje pateikiamą laikraščiu tyrimą), kaip matyti, šis faktas fiksuotas ir tiriant TV, netgi ịvardijant tai kaip tam tikrą profesinę veiklą (aut. past.). 
Tyrimo objektas - lyčių vaizdavimo laikraščių tekstuose ypatybès (19902000 metai).

Tyrimo tikslas - atskleisti lyčių vaizdavimo tendencijas Lietuvos laikraščiu žurnalistikoje tirtuoju laikotarpiu.

Siekiant įgyvendinti tikslą, spręsti šie uždaviniai:

1. Atlikti lyčiai priskirtinų tekstų laikraščiuose semantinę ir statistinę analizę.

3. Išskirti moterų ir vyrų vaizdavimo ypatybes tirtų laikraščių tekstuose.

Metodai: turinio (content) analizé, lyginimas, procentinè, koreliacinė analizės, $\chi^{2}$ kriterijus.

\section{Semantinių segmentų laikraščiu tekstuose tyrimo procedūros}

Tyrimo imties formavimo laikmetis - pirmasis Lietuvos Nepriklausomybès dešimtmetis (1990-2000 metai). Siekiant panoraminio lyties atspindejimo vaizdo, pasirinkti besiskiriantys auditorijos apréptimi - nacionaliniai, kraštų, apskričių bei rajonų - laikraščiai: „Lietuvos rytas“, „Respublika“, „Klaipėda“, „Šiaulių kraštas“, „Vakarų ekspresas“, „Banga“, „Būdas žemaičių“, „Valsčius“, „Vienybë“, „Pamarys“, „Santarvé“. Straipsnių imčiai sudaryti taikytas turinio (content) analizės metodas, atrankos kriterijus - vyras arba moteris, kaip pagrindiniai tekste aprašyti veikejjai. Iš viso išanalizuoti 749 straipsniai, kuriuose aprašomi vyrai (363 tekstai) ir moterys (386 tekstai).

Reikšmių, siejamų su lytimi, analizei atlikti sudarytas 67-ių bazinių žodžiu (ir teigiamos, ir neigiamos konotacijos) sąrašas, atspindintis emocijas, poelgius, darbą, buitị, santykius, būsenas, įvykius, savybes, gyvenimo būdą, vaidmenis. Tyrimo metu šis sąrašas koreguotas, paradigminès bazinès sąvokos papildytos susijusiomis reikšmėmis, išryškejusiomis imties tekstuose, pvz., bazinė sąvoka stiprumas papildyta šiomis: jèga, energija, tvirtas, fizinis pasirengimas, ištvermé; feminizmas: emancipacija, lygios teisès. Tokie vienetų kompleksai toliau čia vadinami segmentais. Iš minètuose 749 straipsniuose atrastų segmentų sudaryta duomenų bazè (duomenų bazèje kiekvienas straipsnis koduotas atskiroje horizontalioje eilutėje, fiksuojant ten esančius segmentus, pateikiamus vertikaliose eilutėse kaip 67 skirtingi variantai). SPSS programa apdoroti duomenys, skaičiuojant segmentų dažnius bei tarpusavio koreliacijas. Fiksuotos lyčių atspindèjimo sąsajos.

Čia pateikiami tekstų atkarpų pavyzdžiai, iliustruojantys stiprumo ir feminizmo segmentus:

- „Vidmantas Urbonas [...] - pasaulio čempionas. Dabar Jus vadina geležiniu žmogumi. Vaikystejje buvote gatvès žmogus. Gal geležinę jègą ir ištvermę užgrūdino vaikų namai ir internatas? - „Galèjo būti ir taip“ 
(R. Žadeikytè. „Abipus galimybių ribos“. Šiaulių kraštas, 2000, Nr. 12 , p. 3).

- „Tikras vyras“ iprasta to žodžio prasme - pirmiausia geras patinas, vyro jèga - pirmiausia jo vyriška jèga“" (I. Konas. ,Tikras vyras“: mitai ir realybé“". Klaipéda, 1990, Nr. 11, p. 10).

- „Feministès „Klèties“ narès, dvejus metus rengusios privataus pobūdžio susitikimus, kovo 8-osios vakarą prie raudonų tulpių puokštės ir su raudono vyno taure rankoje diskutavo apie klaidingą feminizmo supratimą mūsų visuomenèje, apie žmonių susvetimèjimą, apie feminizmo įtaką bekulnei patogiai avalynei bei laisviems drabužiams, apie liemenėlių ir korsetų žalą ir privalumus bei vyrus nevykèlius“ (L. Valatkienè. „Feministès nusprendè paskelbti savo idèjas“. Lietuvos rytas, 1994, Nr. 47 (991), p. 11).

- „Supratau, kad Šiluteje dar yra labai daug vyrų, kurie nesuvokia, kad moterys yra lygiavertès ir lygiateisès šios planetos gyventojos, o ne kažkokie padarai, kurie būtinai turi rodyti savo grožị (V. Vaičiulytė. „Šilutès vyrai ateiviai iš 19 amžiaus“. Pamarys, 1998, Nr. 40 (1135), p. 4).

\section{Lyčių atspindèjimo skirtumai: procentiniai dažniai, $\chi^{2}$ kriterijus ir koreliacinè analizè}

Tarpusavyje lyginti tekstai apie moteris ir vyrus pagal konkrečių segmentu atspindèjimo dažnius juose. Toliau pateikiami tik statistiškai reikšmingi skirtumai tarp moters ir vyro vaizdavimo, kurie atitinka $\chi^{2}$ patikimumo sąlygą $p<0,01$. Galima tik pastebėti, kad vienos lyčiai priskirtinos reikšmès laikraščiuose dažnesnès, kitos - retesnès. Duomenys pateikti lentelèje, čia pajuodintu šriftu išskirtos moterų vaizdavimui būdingesnès reikšmès, neparyškintu - vyrų.

Greta aptariami ir nustatyti segmentų tarpusavio ryšiai, atspindintys lytis.

Kaip matyti iš rezultatų, išryškejjo natūraliai lytims priskiriamas, tačiau nelygiavertis dažniais reikšmių kompleksas tekstuose, pirmiausia vertinant motinystès ir tèvystès segmentus: statistiškai tèvystė tekstuose apie vyrus aktualizuojama daug mažiau nei motinystė tekstuose apie moteris (plg. $12 \%$ ir $30 \%$ ). Dėl pastarojo fakto, dažnesnès ir motinos bei vaikystès sąsajos, nors atrodytų, kad tèvo vaidmuo ne mažiau svarbus, pirmiausia žvelgiant iš vaiko pozicijų. Atlikus koreliacinę analizę nustatyti tiek moterims, tiek ir vyrams būdingi stiprūs segmentų ryšiai tekstuose, atskleidžiantys šeimos tematiką apskritai: motinysté - vaikystè (koreliacijos koeficientas $r=0,747)$, tèvas - vaikysté $(r=0,632)$, tévas - šeimyniniai santykiai $(r=0,452)$, motinystè - šeimyniniai santykiai $(r=0,497)$, nors, kaip minèta, šios reikšmių struktūros dažnesnès tekstuose apie moteris. 
1 lentele . Lyčių atspindèjimo skirtumai: procentiniai dažnai ir $\chi^{2}$ kriterijus (čia $d f=1, p<0,01$ )

\begin{tabular}{|c|c|c|c|}
\hline Bazinis segmento žodis & $\begin{array}{l}\text { Procentiniai dažniai } \\
\text { tekstuose apie moteris }\end{array}$ & $\begin{array}{l}\text { Procentiniai dažniai } \\
\text { tekstuose apie vyrus }\end{array}$ & $\chi^{2}$ \\
\hline vyriškas darbas & $3 \%$ & $30 \%$ & 100,07 \\
\hline grožis & $29 \%$ & $4 \%$ & 77,58 \\
\hline motinystè & $30 \%$ & $7 \%$ & 60,84 \\
\hline moteriškas darbas & $33 \%$ & $10 \%$ & 57,45 \\
\hline krašto apsauga & $3 \%$ & $15 \%$ & 32,52 \\
\hline tèvas & $3 \%$ & $12 \%$ & 25,40 \\
\hline stambūs nusikaltimai & $4 \%$ & $14 \%$ & 24,64 \\
\hline sportas & $3 \%$ & $12 \%$ & 23,63 \\
\hline apranga & $11 \%$ & $3 \%$ & 20,81 \\
\hline hobis & $2 \%$ & $9 \%$ & 20,62 \\
\hline nugalèti & $4 \%$ & $14 \%$ & 19,25 \\
\hline vaikystė & $30 \%$ & $17 \%$ & 16,58 \\
\hline drąsa & $7 \%$ & $16 \%$ & 15,00 \\
\hline nelaimè & $9 \%$ & $18 \%$ & 13,68 \\
\hline išskirtinè asmenybė & $10 \%$ & $19 \%$ & 13,67 \\
\hline erotika & $16 \%$ & $7 \%$ & 13,60 \\
\hline smulkūs nusikaltimai & $10 \%$ & $20 \%$ & 13,19 \\
\hline kūno išvaizda & $14 \%$ & $6 \%$ & 12.21 \\
\hline nepadorumas & $7 \%$ & $2 \%$ & 11,91 \\
\hline stiprumas & $18 \%$ & $29 \%$ & 11,59 \\
\hline egoizmas & $4 \%$ & $10 \%$ & 11,51 \\
\hline kuklumas & $5 \%$ & $1 \%$ & 10,91 \\
\hline alkoholis & $8 \%$ & $14 \%$ & 8,37 \\
\hline paliktas vaikas & $6 \%$ & $2 \%$ & 7,90 \\
\hline mandagumas & $2 \%$ & $6 \%$ & 7,33 \\
\hline socialinès garantijos & $14 \%$ & $8 \%$ & 6,65 \\
\hline maitinimas & $10 \%$ & $5 \%$ & 5,88 \\
\hline feminizmas & $5 \%$ & $2 \%$ & 5,69 \\
\hline
\end{tabular}

Bazinė sąvoka paliktas vaikas taip pat labiau priskirtina moterims, nors apie tai rašoma nedaug (žr. 1 lentelę). Galima svarstyti, ar vyrai, paliekantys šeimas, nepalieka savo vaikų? Atkreiptinas dėmesys, kad tekstuose apie vyrus paliktas vaikas siejamas su feminizmu $(r=0,272)$ ir tai vienintelis rastasis ryšys, taigi, vaizdžiai tariant, ir čia „kalta“ moteris. O štai tekstuose apie moteris, kuriuose kalbama apie palikta vaika, koreliacijų nustatyta daugiau: su būdingesniu vyrams egoizmu $(r=0,402)$ bei alkoholiu $(r=0,343)$, taip pat išdavyste $(r=0,378)$ ir apsileidimu $(r=0,256)$. 
Grižtant prie mažiausiai laikraščiuose procentiniais dažniais atskleistos feminizmo tematikos tekstuose apie moteris, norètųsi atkreipti dèmesị i pastebėtą gana stiprią koreliaciją tarp feminizmo ir naujoviu $(r=0,369)$. Prisiminus tirtų tekstų laikmetị (žr. aukščiau Tyrimo procedūras) matyti, kad ši tematika, Lietuvai atgavus nepriklausomybę, išties buvo naujovè.

Kalbant apie darbų pasiskirstymą tarp moterų ir vyrų reikètų pastebėti, kad pradiniame tyrimo etape buvo išskirtas bazinis žodis darbas su jam giminingomis reikšmėmis, tačiau atliekant tekstų analizę išryškejjo akivaizdžios konkrečių darbų prieskyros lytims, taigi gauti visiški moterišku ir vyrišku darbų, atspindimų laikraščiuose, skirtumai, rodantys tendenciją palaikyti tradicinę moteriško ir vyriško darbo sampratą. Tiek moteriški, tiek vyriški darbai koreliuoja su konkrečia profesija (atitinkamai $r=0,626$ ir $r=0,546$ ), vyriškiems darbams dar priskiriama kompetencija $(r=0,355)$, o moteriškiems - atsakomybe, nors fiksuotas tik silpnas ryšys $(r=0,214)$.

Netenka nustebti, kad tekstuose apie moteris palaikomas jų, kaip gražiosios lyties, stereotipas - akivaizdu, jog apie vyrų grožị rašyti neịprasta, nors kasdienybejje pasakymas ,gražus vyras (vaikinas)“ ne toks ir retas. Kaip matyti iš rezultatų, apranga, kūno išvaizda taip pat labiau aktualizuojama straipsniuose apie moteris, nors ị šių segmentų kompleksą įtrauktos ir su vyrais labiau siejamos sąvokos, pvz., kostiumas, kaklaraištis, barzda, raumenys. Erotikos segmento „aktyvumas“ tekstuose apie moteris taip pat nekelia nuostabos stereotipizacijos prasme - jis gana dažnas (penktas pagal procentinius dažnius).

Atlikus koreliacinę analizę nustatyta, kad grožio $(r=-0,285)$, kūno išvaizdos $(r=-0,220)$, erotikos $(r=-0,236)$, aistros $(r=-0,236)$ ir puoštis $(r=-0,209)$ segmentai turi neigiamus, nors ir silpnus ryšius su motinyste. Tai rodo, kad laikraščių tekstuose apie moteris koreliacinio lauko kryptingumas būna dvejopas: arba juose atspindima moteris - motina, arba moteris - gražioji lytis. Ši tendencija pavaizduota 1 paveiksle.

Gal kiek neịprasta, kad neatrasta instinktu (,motiniški instinktai“) segmento ryšio su motinyste - tik su emocijomis $(r=0,227)$.

Galima pastebèti ir ịdomią kuklumo - nepadorumo opoziciją, labiau atrandamą tekstuose apie moteris nei apie vyrus, nors, kaip matyti iš procentinių dažnių, laikraščiuose tai nèra labai populiarūs segmentai. Gal tik paminètina, kad nepadorumas tekstuose apie moteris turi ryši tik su lengvabüdiškumu $(r=0,288)$, o štai tekstuose apie vyrus - ne tik su pastaruoju ir dar stipresni $(r=0,394)$, bet ir su instinktais $(r=0,348)$ bei seksualine prievarta $(r=0,230)$. Taigi, kaip matyti iš koreliacinès analizès rezultatų, vyrų nepadorumas tekstuose atspindimas, nors ir rečiau nei moterų, bet semantiškai išraiškingiau. 


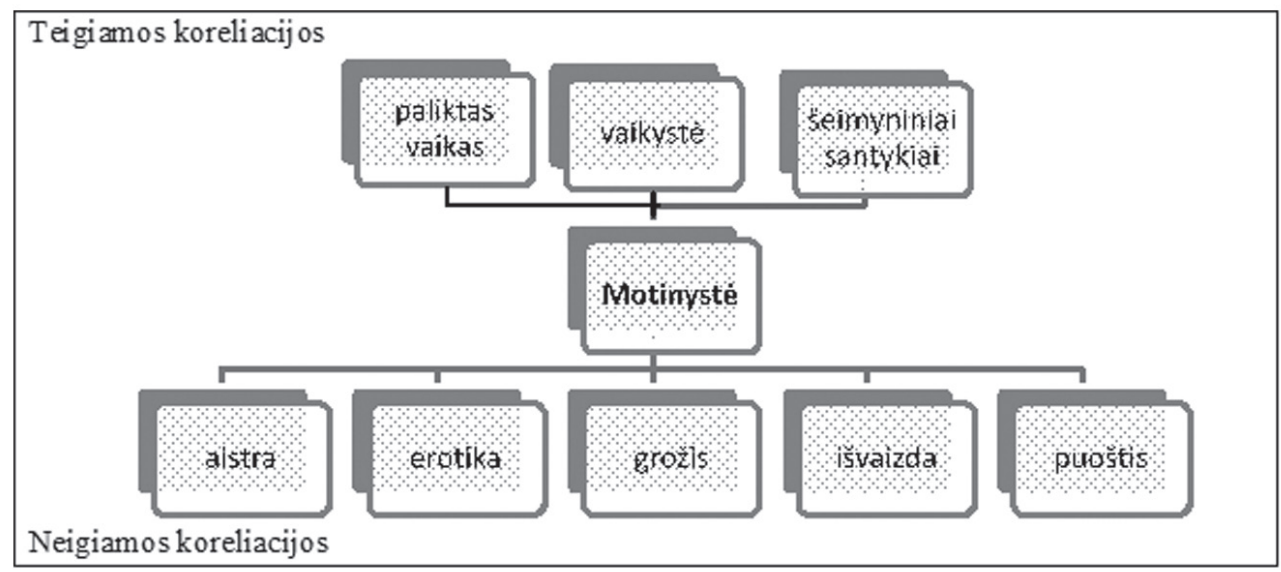

1 pav. Motinystès semantinio segmento koreliacijų schema

Žvelgiant ị procentinius dažnius lentelèje matyti, kad tekstuose apie moteris labiau nei apie vyrus, aktualizuojamos socialinès garantijos, kurios, kaip rodo koreliacijos, susijusios su sunkumais $(r=0,308)$, o šie - su motinyste $(r=0,270)$. Socialines garantijos išryškejja ir tekstuose apie vyrus: čia jos taip pat turi ryšį su sunkumais $(r=0,249)$ ir, kitaip nei tekstuose apie moteris, - su šeimyniniais santykiais $(r=0,220)$.

Žinomas stereotipas, kad vyrai yra šeimos maitintojai, tekstuose apie vyrus nepakankamai atspindimas: maitinimo segmentas labiau priskiriamas moterims, bet tai, viena vertus, susiję su maitinimo proceso reikšmių lauku (virtuvè, puodai), tradiciškai būdingesniu moterų veiklai, kuri dažniau ir aprašoma, pvz., nustatyti aptariamojo segmento ryšiai su tokiais, kaip namu ruoša $(r=0,343)$, namu ūkis $(r=0,352)$. Kita vertus, tikètasi, kad žodžiai „duona“ („uždirbti duoną“), ,arti“, „verslas“ ir pan., po bandomojo tyrimo ịtraukti i captariamojo segmento kompleksą, išryškins vyro, kaip šeimos maitintojo, stereotipą, tačiau tenka konstatuoti, kad pastarojo raiška tirtuose tekstuose yra silpna: pasitelkiant koreliacinès analizès rezultatus išryškejjo, kad tekstuose apie vyrus maitinimas turi tik vieninteli silpną ryšị $(r=0,233)$ su šeimyniniais santykiais.

Vertinant dar neaptartus statistiškai reikšmingus vyrų skirtumus matyti, kad vyrai, būdami stiprūs, drąsūs, norintys nugalèti, yra tinkami krašto apsaugai, sportui, apie juos dažniau kalbama, kaip apie išskirtines asmenybes. Žvelgiant ị koreliacinès analizès duomenis išryškejjo, kad šios reikšmès tarpusavyje susijusios ir būdingos pirmiausia sporto tematikos tekstams: nugaleti - sportas $(r=0,693)$, stiprumas sportas $(r=0,381)$, išskirtine asmenybe - sportas $(r=0,315)$, nugalèti - išskirti$n \dot{e}$ asmenybe $(r=0,363)$. O štai drąsa, nors ir silpnai, siejama su krašto apsanga $(r=0,230)$. 
Vyrai, lyginant su moterimis, daugiau ịvykdo stambiu ir smulkiu nusikaltimu, kurie, kaip rodo koreliacinès analizès duomenys, susiję su alkoholiu $(r=0,336)$, nelaime $(0,418)$, egoizmu $(r=0,264)$, pastarasis - dar ir su teistumu $(r=0,289)$ bei lengvabūdiškumu $(r=0,230)$. Nustatyta ir tai, kad vyrai neretai linkę nusikalsti jauni (nusikaltimai - jaunyste koreliacijos koeficientas $r=0,240$ ). Kalbant apie jaunystès segmentą tekstuose apie moteris, jis susijęs tik su grožiu $(0,230)$.

Hobis, kaip tekstams apie vyrus būdingesnè reikšmè, yra gana „išsiskaidžiusi“ sraipsnių imtyje, nes neatrasta nei vieno ryšio, rodančio sąsajas su kuriuo nors segmentu. Taigi apie vyrų pomėgius rašoma gana epizodiškai ir įvairiuose kontekstuose, nors ir reikšmingai dažniau, nei apie moterų.

İdomios sąsajos atsiskleidè analizuojant mandagumo, kuriuo vyrai skiriasi nuo moteru tekstuose apie juos, segmentą: pastarasis koreliuoja su moterimi $(r=0,255)$, moteriškais darbais $(r=0,286)$ bei apranga $(r=0,249)$, t. y. reikšmèmis, kurios tekstuose apie moteris - prioritetinès (žr. 3 lentelę). Taigi matyti, kad vyrų mandagumas labiausiai siejamas su moterimis.

Toliau lentelèse pateikiamos tekste jau aptartos būdingiausios tarpusavyje teigiamai koreliuojančių semantinių segmentų struktūros, susidarančios atskirai tekstuose apie moteris (2 lentelè) ir atskirai - apie vyrus (3 lentelè).

2 lentele. Semantinių segmentų sąsajos laikraščių tekstuose apie moteris

\begin{tabular}{|l|l|}
\hline & Tekstai apie moteris \\
\hline Pagrindinis segmentas & Susiję segmentai \\
\hline Paliktas vaikas & egoizmas, alkoholis, išdavystė, apsileidimas \\
\hline Moteriškas darbas & profesija, atsakomybė \\
\hline Nepadorumas & lengvabūdiškumas \\
\hline Socialinės garantijos & sunkumai - motinyste் \\
\hline Maitinti & namų ruoša, namų ūkis, atsakomybe் \\
\hline
\end{tabular}

3 lentelè. Semantinių segmentų sąsajos laikraščių tekstuose apie vyrus

\begin{tabular}{|l|l|}
\hline \multicolumn{2}{|c|}{ Tekstai apie vyrus } \\
\hline Pagrindinis segmentas & Susiję segmentai \\
\hline Paliktas vaikas & feminizmas \\
\hline Vyriškas darbas & profesija, kompetencija \\
\hline Nepadorumas & lengvabūdiškumas, instinktai, seksualinè prievarta \\
\hline Socialinės garantijos & sunkumai, šeimyniniai santykiai \\
\hline Maitinti & šeimyniniai santykiai \\
\hline Sportas & nugalèti, stiprumas, išskirtinė asmenybė \\
\hline Krašto apsauga & drąsa \\
\hline Nusikaltimai & $\begin{array}{l}\text { alkoholis, nelaimė, egoizmas - lengvabūdiškumas - teistumas, } \\
\text { jaunystė }\end{array}$ \\
\hline Mandagumas & moteris, moteriški darbai, apranga \\
\hline Tėvas & vaikysté, šeimyniniai santykiai \\
\hline
\end{tabular}


Iš lentelèse pateiktų rezultatų aptartini įdomesni: 1) paliktas vaikas tirto laikmečio laikraščių tekstuose labiau siejamas su moterų neigiamomis savybėmis ar gyvenimo būdu. Tuo tarpu straipsniuose apie vyrus šis aspektas pateikiamas moteru feminizmo kontekstuose, nors ir vyrams būdingas tas pats alkoholis bei egoizmas; 2) moteriški ir vyriški darbai taip pat turi vieną segmentinị skirtumą: moterims labiau priskiriama atsakomybe, vyrams - kompetencija. Klausimas kiltų tik toks: ar tikrai tirtu laikotarpiu moterys neturejjo profesinès kompetencijos? Gal šis stereotipas iki šiol ir yra mažesnio moterų atlygio už darbą, apie kurị vis kalbama, priežastis? 3) socialiniu garantiju segmento tyrimas rodo bendrą sunkumu vardiklį tekstuose apie abi lytis, tačiau semantinèse struktūrose jis skaidosi: moterims labiau aktualizuota motinystè, vyrams - šeimyniniai santykiai. Šiuo atveju galima būtų pastebèti fiksuotą „moters - motinos“ ir „vyro - šeimos galvos“ stereotipo raišką, atkreipiant dėmesị ir ị segmento maitinti išsiskaidymą, kai vyrams priskiriami tie patys šeimyniniai santykiai (jau aptarti aukščiau), o moterims - namu ruoša, namu ūkis ir ta pati atsakomybé.

\section{Lyčių atspindėjimo panašumai}

Dalis tirtų segmentų tiek tekstuose apie vyrus, tiek - apie moteris pavartoti itin panašiu dažniu (nuo identiškų iki kelių procentinių punktų skirtumo), taigi akivaizdu, kad statistiškai reikšmingų skirtumų tarp šių segmentų būti negalètų. Tai rodo, kad tam tikri segmentai tekstuose apie abi lytis tirtu laikotarpiu turejjo panašią raišką ir pastarają galima būtų ịvardyti kaip subalansuotą, t. y. nepriskirtiną kuriai nors lyčiai taikomai stereotipų struktūrai. Toliau pateikiami šie identiški arba labiausiai sutampantys segmentai (procentiniais dažniais): jaunyste (identiškai po $15 \%$ ), žmona (tekstuose apie moteris - $10 \%$, apie vyrus - $11 \%$ ), nuteisti (analogiškai $10 \%$ ir $11 \%$ ), išdavyste (identiškai po $7 \%$ ), netikęs (po $10 \%$ ), svetimas (po $5 \%$ ), atsakomybe (19\% ir $21 \%$ ), ugdymas (po $11 \%$ ), protingumas (4\% ir $6 \%$ ), ryžtingumas (po $13 \%$ ), išdidumas (po $4 \%$ ), draugiškumas (9\% ir $8 \%$ ), profesionalumas (8\% ir $11 \%$ ), juokauti (po $5 \%$ ), švente (10\% ir $9 \%)$, instinktai (6\% ir $5 \%$ ), pavydas (1\% ir $2 \%$ ), frigidiškumas / impotencija (po $1 \%$ ), dvasingumas $(5 \%$ ir $3 \%)$.

Kaip matyti, yra ne tik savaime suprantamų panašumų, pvz., išdavyste, kuri būdinga abiems lytims, bet ir kiek netikètų, pvz., ugdymas, kuris paprastai labiau priskiriamas moterims, o tyrimo rezultatai rodo, kad ši funkcija tekstuose atspindima vienodai dažnai.

\section{Išvados}

Atlikus 749 straipsnių (1990-2000 metų, skirtingų auditorijos apréptimi laikraščių) semantinę analizę, kurių pagrindiniais veikejjais buvo vyrai arba moterys, nustatyta, kad statistiškai tėvystės segmentas tekstuose apie vyrus aktualizuojamas 
daug rečiau nei motinystės segmentas tekstuose apie moteris, tačiau abiem atvejais pastebèti stiprūs segmentų, atspindinčių šeimos tematiką, ryšiai tekstuose. Išryškejjo akivaizdžios konkrečių darbų prieskyros lytims: gauti visiški moteriškų ir vyriškų darbų, atspindimų laikraščiuose, skirtumai, rodantys tendenciją palaikyti tradicinę moteriško ir vyriško darbo sampratą. Tekstuose apie moteris koreliacinio lauko kryptingumas nustatytas dvejopas: arba juose atspindima moteris - motina, arba moteris - gražioji lytis ir, ịvertinus procentinius abiejų ịvaizdžiu dažnius, galima konstatuoti, kad abu jie lakraščiuose pateikiami vienodai. Vyrai, lyginant su moterimis, laikraščiuose daugiau aprašomi tekstuose apie nusikalstamumą, kuris, kaip tema žiniasklaidoje apskritai, itin populiarus.

Žvelgiant ị laikraščių tekstų tyrimo procentinès, statistiškai reikšmingų skirtumų bei koreliacinès analizès rezultatus, apibendrinant galima konstatuoti, kad nustatyti ryškiausi semantinių segmentų kompleksai (galimi dar įvardyti semantiniais laukais), kurie būdingi lyčių vaizdavimui tirtų 1990-2000 m. laikraščių tekstams: abiejų lyčių funkcijų laukas: motinystè, tévas, vaikysté, šeimyniniai santykiai, paliktas vaikas (nors ir skirtinguose lytims priskiriamuose kontekstuose). Vyru veiklos segmentai: vyriški darbai, krašto apsauga, nusikaltimai, sportas, hobis, moterų - moteriški darbai, maitinimas. Moterų ypatybès: apranga, grožis, kūno išvaizda, nepadorumas, kuklumas, erotika, vyru - stiprumas, drąa, nugalèti, išskirtine asmenybè, egoizmas, alkoholis, mandagumas (pastarasis, kaip nustatyta, skirtas moterims).

Akcentuotina, kad žiniasklaidos produkciją kuria lytys, vienaip ar kitaip jas ir atspindėdamos, palaikydamos arba ne stereotipus apie moteris bei vyrus. Žinant laikraščiu žurnalistikos feminizacijos proceso tendencijas, natūraliai kyla klausimas: tai kaip laikraščių tekstuose norètų / galètų būti vaizduojamos moterys ir ką būtinai reikètų pasakyti apie vyrus, paisant lygių raiškos (ar saviraiškos) galimybių? Akivaizdu, kad norint atsakyti i pastaraji klausimą, optimalu būtu atlikti antrojo Lietuvos nepriklausomybès dešimtmečio laikraščių tekstų analizę bei palyginti su pirmojo dešimtmečio rezultatais.

Gauta 20160910

Pasirašyta spaudai 20161015

\section{Literatūra}

Aidis, R. (1999). Moterų verslininkių problemos. Moterys: tapatumo paieškos, p. 58-75. Vilnius: Moterų informacijos centras. ISBN 9986523664.

Armstrong, L. C., Wood, L. M. M., Nelson, R. M. (2006). Female News Professionals in Local and National Broadcast News During the Buildup to the Iraq War. Journal of Broadcasting \& Electronic Media [interaktyvus], Vol. 50, Issue 1, p. 78-94. Prieiga per EBSCO [žiūrèta 201305 02]. ISSN 1550-6878.

Astrauskaitè, I. (2005). Pokyčiai žurnalistų sociume lyties aspektu. Baltijos šalių žiniasklaidos transformacijos: jaunujų tyrèjų požiūris, p. 62-67. Kaunas: Vytauto Didžiojo universiteto leidykla. ISBN 9955121149. 


\section{Daiva Sirtautienè}

Cotter, C. (2011). Women's place at the Fourth Estate: Constraints on voice, text, and topic. Journal of Pragmatics [interaktyvus], Vol. 43, Issue 10, p. 2519-2533. Prieiga internete: $<$ http://www.sciencedirect.com/science/ article/pii/S0378216611000567> [žiūrèta 201303 05]. ISSN 1879-1387.

Desmond, R., Danilewicz, A. (2010). Women Are On, But Not In, the News: Gender Roles in Local Television News. Sex Roles [interaktyvus], Vol. 62, No. 11-12, p. 822-829. Prieiga per EBSCO [žiūrèta 201304 08]. ISSN 1573-2762.

Djerf-Pierre, M. (2007). The Gender of Journalism. The Structure and Logic of the Field in the Twentieth Century. Nordicom Review [interaktyvus], Jubilee Issue 2007, p. 81-104. Prieiga internete: <http://www.nordicom. gu.se/common/publ_pdf/248_248_djerf-pierre1.pdf> [žiūrèta 2013 04 09]. ISSN 1403-1108.

Holter, Ø. (2005). Ar vyrai sugebès? Vyrai ir lyčiu lygybè: Šiaurès šaliu patirtis. Vilnius: Lygių galimybių plètros centras. ISBN 9955-605-16-2.

Kazinec, A. (2008). Moters ịvaizdis viešojoje erdvejje. Magistro darbas [interaktyvus]. Prieiga per duomenu bazę eLABa: <http://vddb.library.lt/fedora/get/LT-eLABa-0001:E.02 2008 D_20080924_184431-15267/ DS.005.0.01.ETD> [žiūreta 201211 10].

Li, X., Lei, M. (2010). Women and Media: A Study on the Marginalization of Female Discourse Power. Crosscultural Communication [interaktyvus], Vol. 6, No. 1, p. 47-55. Prieiga per EBSCO [žiūrèta 201210 16]. ISSN 1923-6700.

Liukinevičienè, L. (2005). Regioniniai Lietuvos dienraščiai lyčių partnerystès ugdyme. Socialiniai tyrimai, Nr. 1(5). p. 95-104. ISSN 1392-3110.

Mater, N. (2007). Reversing the Situation in the Media. Gender-based journalism [interaktyvus], p. 167-196. Prieiga internete: <http://eski.bianet.org/belgeler/Kadin_\%20 Odakli_Habercilik_English.pdf> [žiūrèta 201303 05]. ISBN-13 978-975-01484-1-5.

Matkevičienè, R. (2003). Lyčių socialiniu stereotipų formavimas Lietuvos televizijų laidose. Informacijos mokslai, Nr. 25, p. 72-80. ISSN 1392-0561.

Sirtautas, V. V., Sirtautienė, D. (2013). Visuomenės vertybinių prioritetų raiška Lietuvos respublikiniuose dienraščiuose. Tiltai, Nr. 3 (64), p. 83-101. ISSN 1392-3137.

Sirtautienė, D., Samulionytė, V. (2015). Lyčių raiška ir kaita laikraščių žurnalistikoje per pirmaji Lietuvos nepriklausomybẻs dvidešimtmetį. Informacijos mokslai, Nr. 71, p. 68-83. ISSN 1392-0561.

Sirtautienè, D., Sirtautas, V. V. (2013). Televizijos reklamos elementu efektyvumas. Mokslo studija. Klaipèda: Klaipedos universiteto leidykla. ISBN 978-9955-18-715-8.

Stonkienė, M. (2003). Vyraujantys šeimos modeliai ir lyčių socialiniai stereotipai Lietuvos žurnaluose, skirtuose paaugliams. Informacijos mokslai, Nr. 25, p. 81-93. ISSN 1392-0561.

Stundžè, L. (2016). Lyčių studijų mokslo komunikacija 1992-2012 metų periodinių leidinių straipsniuose. Informacijos mokslai, Nr. 74, p. 111-125. ISSN 1392-0561.

Stundžè, L. (2009). Lytis ir organizacija: komunikacinis aspektas. Informacijos mokslai, Nr. 49, p. 99-117. ISSN 1392-0561.

Stundžienė, L. (2002). Stereotipų ịtaka lyčiu komunikacijai. Feminizmas, visuomenè, kultūra, Nr. 4, p. 11-16. ISSN 1648-1585.

Tereškinas, A. (2004). Vyrai, vyriškumo formos ir maskulinizmo politika šiuolaikinëje Lietuvoje. Vilnius: Sapnų sala. ISBN: 9955611030.

Trinkūnienė, I., Trinkūnas J. (1999). Patriarchalizmo apraiškos lietuviškoje tradicijoje. Moterys: tapatumo paieškos, p. 36-47. Vilnius: Moteru informacjos centras. ISBN 9986523664.

Willis, J. (2010). The mind of a journalist: how reporters view themselves, their world, and their craft. Los Angeles: Sage. ISBN 1412954576.

Žvinklienè, A. (2009). Lyčių atotrūkis ir patriarchato raiška Baltijos valstybėse. Lietuvos ypatumai. Sociologija. Mintis ir veiksmas [interaktyvus], Nr. 1(24), p. 99-118. Prieiga internete: <http://www.ku.lt/wp-content/ uploads/2013/04/2009-1p_99-118.pdf> [žiūrèta 201305 02]. ISSN 1392-3358. 


\section{THE PECULIARITIES OF GENDER PORTRAYAL IN LITHUANIAN NEWSPAPER JOURNALISM IN FROM 1999-2000 YEARS}

\section{Daiva Sirtautienè}

\section{Summary}

The article presents the results of semantic analysis based on statistical data of 1990-2000 y. texts about genders published in Lithuanian newspapers. In all 749 articles, which portray men (363) and women (386), were analysed. The research aimed to establish the peculiarities of gender portrayal in texts during the first decade of Lithuania's independence. Segments of meanings, related to genders, and their interrelations in the texts about men and women were distinguished, comparative analysis of gender portrayal differences was conducted.

The semantic analysis in which the main characters are women or men shows that statistically the segment of fatherhood in the texts about men is actualized far less than the segment of motherhood in the texts about women, although in both cases strong connections between segments of the family topic are observed. Apparent attribution of work to genders was revealed, thus absolute differences of male and female work, represented in the newspapers, emerged, which illustrates the tendency to maintain the traditional conception of female and male work. In the texts about women the vector of the correlational field has been observed of two kinds: either it represents a woman-mother or a woman-the more beautiful gender and, considering the percentage frequency of both images, it can be concluded that they are equally portrayed in the newspapers. Men, compared to women, are more often mentioned in texts about delinquency which as a topic is a very popular theme in the media.

In accordance with the results of the percent and correlational analysis, also statistically significant differences, it can be stated that the most conspicuous semantic segment complexes (or - semantic fields) were established that are characteristic to gender portrayal in the analysed 1990-2000 y. newspaper texts: both genders' functions field: maternity, parent, childhood, family relationships, abandoned child (though in different gender-related context). Men's activity segments: masculine work, national defence, crime, sports, hobby, while women's - feminine work, nourishment. Women's characteristics: clothing, beauty, looks, indecency, modesty, erotica, while men's: strength, courage, winning, exceptional personality, egoism, alcohol, politeness (the latter is intended for women as the results suggest). 
It should be emphasized that the production of media is created by genders that reflect the media in one way or another, encouraging or discouraging the stereotypes about men and women. Having in mind the tendencies of feminisation in the newspaper journalism, naturally a question arises: how would women want / be able to be portrayed in the newspapers and what must be said about men, taking the equal rights of expression (or self-expression) into consideration? It seems obvious that in order to answer the latter question, it would be optimal to conduct the analysis of newspapers of Lithuania's independence second decade and compare it to the results from the first decade. 